\title{
COMMUNICATIONS
}

\section{FUNGAL FLORA OF THE CONJUNCTIVAL SAC IN HEALTHY AND DISEASED EYES*}

\author{
BY \\ ROGER AINLEY AND BRENDA SMITH \\ From the Oxford Eye Hospital and the Sir.William Dunn School of Pathology, \\ University of Oxford
}

IN the past 13 years there has been a notable increase in the number of reports of cases of ocular mycosis, a large proportion of which originate in North America (Haggerty and Zimmerman, 1958; Mikami and Stemmermann, 1958; Chick and Conant, 1962). The increase has apparently been associated with the increasing use of topical corticosteroids and wide-spectrum antibiotics (Hogan, Thygeson, and Kimura, 1954; Suie and Havener, 1963; McLean, 1963).

There is experimental evidence for the enhancement of the effects of fungus infection by corticosteroids (Mankowski and Littleton, 1954; Ley, 1956; Hirose, Yoshioka, Abe, Kanemitsu, and Kiya, 1957; Agarwal, Malik, Mohan, and Khosla, 1963), and possibly also by wide-spectrum antibiotics (Tanaka, 1952; Seligmann, 1952, 1953; Ley, 1956). It seems certain that corticosteroids increase the virulence of species that are recognized pathogens, and some authors believe that they will allow species normally regarded as commensals to behave pathogenically (Agarwal and others, 1963; Suie and Havener, 1963).

In the United Kingdom no similar increase has been reported in the incidence of ocular mycosis, yet the use of topical corticosteroids and antibiotics in ophthalmology is probably as frequent here as in North America or Japan. For this apparent discrepancy, which prompted the present investigation, there may be several reasons:

(a) There may be a difference in the pathogenicity of the fungal flora to which the population is exposed in the United Kingdom as compared with other parts of the world, perhaps because of a difference in the range of species to which the population is exposed in each region. If this is the case, the use of topical corticosteroids may be less conducive to ocular mycosis here than in, for example, North America. Since no studies of the mycotic flora of the eye appear to have been published from the United Kingdom, the point cannot yet be decided.

(b) It may be that the frequency of diagnosis of ocular mycosis in the United Kingdom has, in fact, increased, but has not been reflected by a corresponding increase of cases reported in the literature. This seems unlikely.

(c) Possibly the diagnosis rate is lower in the United Kingdom than elsewhere. "Antibiotic-resistant" ocular infections due to fungi may well go unrecognized (Barsky, 1959).

* Received for publication January 7, 1965 . 
Even when the diagnosis is considered it may be difficult to prove, and it is often considered too late, or missed (Weiss, Perry, and Shevky, 1948; Wadsworth, 1951; Ley and Sanders, 1956; Sigtenhorst and Gingrich, 1957; Veirs and Davis, 1958; Anderson, Roberts, Gonzalez, and Chick, 1959).

It would therefore be of interest to know the following facts concerning the population of the United Kingdom:

(a) The range of species of fungus present as commensals in the conjunctival sacs of subjects who show no disease of the outer eye. Such data would serve as a basis for comparison with other parts of the world, and in view of the recent increase in reports of intraocular fungus infection following surgery (which is believed to be exogenous; Fine and Zimmerman, 1959) might indicate the species likely to be responsible for such cases. By analogy, the fungi which produce secondary infection of the skin and mucous membranes following antibiotic treatment are derived from the normal body flora (Smith, 1952).

(b) The effect of topical corticosteroids and antibiotics on the incidence of such fungi.

(c) The proportion of cases of external eye disease from which fungi can be cultured, and the possible role of the fungi in causing the disease.

The present study attempts to throw some light on these questions, and includes a report of a possible case of keratomycosis, believed to be the first reported among the population of the United Kingdom.

\section{Methods}

The subjects used were patients attending Oxford Eye Hospital between April and September, 1963. They were divided into two groups as follows.

Group 1.-43 patients, admitted for cataract extraction or glaucoma surgery, who showed no signis of disease of the outer eye. Their ages ranged from 40 to 85 years; thirty were between 60 and 85 years. All were given a course of betamethasone/neomycin drops or ointment (Betnesol-N, Glaxo) post-operatively. Cultures were taken from the affected eye on admission, and repeated in 21 patients after the medication had been administered at least three times a day for not less than 2 weeks. The intention was to assess the frequency and range of species of fungus present in the normal conjunctival sac, and to observe any effect of a course of the corticosteroid and antibiotic on this flora.

Group 2.-26 patients showing some form of disease of the outer eye or adnexa. Their ages ranged from 11 to 81 years, the majority being in the forties. Serial cultures were taken to try to assess whether the frequency and range of species present differed from those found in patients in whom the outer eye was normal, and also as a screening procedure for any cases in which fungi might be a major cause of disease. Corneal smears from twenty of the patients (including all those whose cultures were positive) were stained and examined microscopically.

Cultures were taken by firm scraping of the upper and lower conjunctival fornices with a flamed platinum loop, care being taken to avoid contact with the lashes or the skin of the lids. The material obtained was transferred direct to sterile Sabouraud glucose broth in bijou bottles and kept at room temperature. The broth was plated out on Sabouraud's agar within a week and the plates incubated at $25^{\circ} \mathrm{C}$. Any resulting colonies were subcultured for identification as necessary. No plate was abandoned as "negative" until it had been kept for 6 weeks (Birge, 1952). In many cases, identification was confined to determination of the genus. Contaminants (bacterial and fungal) were usually easy to recognize, and will not be mentioned further. To assess the rate of contamination, a few blank cultures into which a flamed platinum loop had been dipped were sent for processing disguised as genuine cultures; in no case did a blank culture grow any fungi. 
In twenty of the patients in Group 2, corneal scrapings were taken for culture and for microscopical examination after Gram staining.

\section{Group 1}

\section{Results}

(a) Initial Cultures.-Twelve of the 43 cultures were positive for fungus (27.9 per cent.). The species isolated are given in Table I.

(b) Recultures after drops or ointment for at least 2 weeks.- Six of the 21 cultures were positive for fungus $(28.5$ per cent.). The types of change found are shown in Table II.

Group 2.-Nine of the 26 cultures were positive for fungus (34.6 per cent.). See Table III.

TABLE I

Fungi Isolated from 12 out of 43 Patients with Healthy Eyes

\begin{tabular}{l|c}
\hline \multicolumn{1}{c|}{ Species } & No. of Patients \\
\hline Penicillium sp. & 1 \\
Aspergillus glaucus & 2 \\
Aspergillus flavipes & 1 \\
Candida sp. & 3 \\
Candida sitophila & 1 \\
Rhodotorula sp. & 1 \\
Stachybotrys atra & 1 \\
Botrytis cinerea & 1 \\
Botrytis cinerea + Penicillium sp. & 1 \\
\hline Total & 12 \\
\hline
\end{tabular}

TABLE II

Recultures after Treatment in 21 Patients with Healthy Eyes

\begin{tabular}{l|c|c|c}
\hline \multicolumn{1}{c|}{ Result } & $\begin{array}{c}\text { No. } \\
\text { of } \\
\text { Cultures }\end{array}$ & Before & After \\
\hline $\begin{array}{l}\text { Negative before } \\
\text { Positive after }\end{array}$ & 3 & \{ & $\begin{array}{l}\text { Botrytis sp. } \\
\text { Penicillium }\end{array}$ \\
(1) \\
\cline { 2 - 4 }
\end{tabular}




\section{Genera found in Healthy Eyes}

\section{Discussion}

Surveys of the normal fungal flora of the conjunctival sac have been undertaken by Fazakas $(1935,1953)$ in Europe, by Mitsui and Hanabusa (1955) in Japan, by Hammeke and Ellis (1960) in the United States, and by Azevedo (1962) in South America. Since the number of patients used and the techniques employed vary somewhat, a detailed analysis of their results would probably be of little value, but the following points of comparison are of interest (Table IV). There is close

TABLE III

Bacteria ANd Fungi Isolated from 9 out of 26 Patients with Disease of the Outer Eye

\begin{tabular}{|c|c|c|c|c|}
\hline $\begin{array}{l}\text { Patient } \\
\text { No. }\end{array}$ & Diagnosis & Bacteria & Fungi & Remarks \\
\hline 1 & Conjunctivitis & Staph. aureus & $\begin{array}{l}\text { Stachybotrys sp. } \\
\text { Penicillium sp. }\end{array}$ & \\
\hline 2 & Keratitis & - & $\begin{array}{l}\text { Candida parapsilosis } \\
\text { Penicillium chrysogenum }\end{array}$ & See case report \\
\hline 3 & Perforating injury & 一 & $\begin{array}{l}\text { Penicillium sp. } \\
\text { and unidentified sp. }\end{array}$ & $\begin{array}{l}\text { Steroid/antibiotic } \\
\text { drops for } 11 \text { days } \\
\text { before culture }\end{array}$ \\
\hline 4 & Keratitis & - & Botrytis cinerea & $\begin{array}{l}\text { Herpes simplex } \\
\text { culture positive } \\
\text { Given hydrocortisone } \\
\text { drops by general } \\
\text { practitioner }\end{array}$ \\
\hline 5 & Scleral laceration & - & $\begin{array}{l}\text { Hormodendron sp. } \\
\quad(=\text { Cladosporium })\end{array}$ & - \\
\hline 6 & $\begin{array}{l}\text { Recurrent } \\
\text { Meibomian cysts }\end{array}$ & Staph. aureus & Mucor sp. & $\begin{array}{l}\text { Steroid/antibiotic } \\
\text { drops for } 8 \text { weeks } \\
\text { before culture }\end{array}$ \\
\hline 7 & Keratitis & - & Alternaria sp. & Herpes simplex \\
\hline 8 & $\begin{array}{l}\text { Lacrimal } \\
\text { canaliculitis }\end{array}$ & $\begin{array}{l}\text { Alpha- } \\
\text { haemolytic } \\
\text { streptococcus }\end{array}$ & Actinomyces sp. & $\begin{array}{l}\text { Culture of } \\
\text { canaliculus } \\
\text { contents }\end{array}$ \\
\hline 9 & $\begin{array}{l}\text { Phakolytic } \\
\text { glaucoma }\end{array}$ & 一 & Penicillium sp. & $\begin{array}{l}\text { Steroid/antibiotic } \\
\text { drops for } 3 \text { months } \\
\text { before culture }\end{array}$ \\
\hline
\end{tabular}

TABLe IV

Frequency of Positive Cultures from Healthy Eyes

\begin{tabular}{l|c|c|c|c|l}
\hline \multicolumn{1}{c|}{ Authors } & Date & No. of Eyes & No. Positive & Per cent. Positive & \multicolumn{1}{|c}{ Region } \\
\hline Fazakas & $(1934)$ & 160 & 39 & $24 \cdot 3$ & Central Europe \\
Fazakas & $(1953)$ & 993 & 253 & $25 \cdot 4$ & Central Europe \\
Mitsui and Hanabusa & $(1955)$ & 65 & 12 & $18 \cdot 4$ & Japan \\
Hammeke and Ellis & $(1960)$ & 356 & 32 & $10 \cdot 3$ & Arkansas \\
Azevedo & $(1962)$ & 12 & 0 & 0 & Brazil \\
Present Study & $(1965)$ & 43 & 12 & $27 \cdot 9$ & England \\
\hline
\end{tabular}


agreement between the results obtained in England and on the European mainland, and the percentages are of the same general order as those for the United States and Japan. It is difficult to explain the findings in Azevedo's series; from the numbers available it would be hazardous to decide whether a real difference in fungal flora exists, due, for example, to local differences in climate or season. Variations in frequency between different geographical areas certainly do occur in particular species, e.g. Sporotrichum (Gordon, 1947; McGrath and Singer, 1952), and Candida sp. (Urrets-Zavalía, Remonda, and Ramacciotti, 1958). As a further example, Penicillium and Aspergillus are not dissimilar organisms, yet the former can exist at a lower optimum temperature and predominates in temperate climates, whereas the latter, requiring a higher optimum temperature but less moisture, thrives in the tropics. Ecological differences of this kind would doubtless explain much of the variation found among the fungal flora of different regions, but it is doubtful whether they alone are sufficient to account for Azevedo's results. Another possibility is that the patients used in his survey might have been young; Hammeke and Ellis (1960) have clearly shown that in children below the age of 16 years the incidence of positive cultures is lower ( 4.8 per cent.) than in adults $(10.3$ per cent.). Azevedo's twelve subjects were selected at random, but their ages are not given.

Some of the genera isolated in the present study and by Fazakas (1953), Mitsui and Hanabusa (1955), and Hammeke and Ellis (1960) are compared in Table V. Aspergillus, Rhodotorula, Candida, and Penicillium appear to be common inhabitants of the healthy conjunctival sac. It is apparent from other data given by Mitsui and Hanabusa (1955) that Candida sp. may also be commonly isolated in Japan, though not represented in their "normal" series. Fazakas (1953) noted that the majority of fungi isolated from the healthy eye were moulds; and in fact, of his 253 positive cultures, 71 were of the genus Penicillium. Of course, each genus listed includes a diversity of organisms; different species vary in pathogenicity, and within each species there may be different strains which likewise vary. Hence, from the above data, no comparisons can be made between the relative pathogenicity of the conjunctival flora found in the four surveys.

TABLE V

Genera Isolated from Healthy Eyes

\begin{tabular}{|c|c|c|c|c|}
\hline Genera & $\begin{array}{c}\text { Fazakas } \\
\text { (1953) }\end{array}$ & Mitsui and Hanabusa & $\begin{array}{l}\text { Hammeke and Ellis } \\
(1960)\end{array}$ & Present Study \\
\hline $\begin{array}{l}\text { Common } \\
\text { to All }\end{array}$ & Aspergillus & Aspergillus & Aspergillus & Aspergillus \\
\hline $\begin{array}{l}\text { Common } \\
\text { to Three }\end{array}$ & $\begin{array}{l}\text { Candida } \\
\text { Penicillium }\end{array}$ & $\begin{array}{c}\text { Rhodotorula } \\
\text { - }\end{array}$ & $\begin{array}{l}\text { Rhodotorula } \\
\text { Candida } \\
\text { Penicillium }\end{array}$ & $\begin{array}{l}\text { Rhodotorula } \\
\text { Candida } \\
\text { Penicillium }\end{array}$ \\
\hline $\begin{array}{l}\text { Common } \\
\text { to Two }\end{array}$ & $\begin{array}{l}\text { Botrytis } \\
\text { Cladosporium } \\
\text { Alternaria } \\
\text { Saccharomyces } \\
\text { Schizosaccharomyces } \\
\text { Mucor }\end{array}$ & $\begin{array}{l}- \\
\overline{-} \\
\text { Saccharomyces } \\
\text { Schizosaccharomyces } \\
\text { Mucor }\end{array}$ & $\begin{array}{l}\text { Cladosporium } \\
\text { Alternaria } \\
- \\
-\end{array}$ & $\begin{array}{c}\text { Botrytis } \\
= \\
= \\
=\end{array}$ \\
\hline
\end{tabular}




\section{Effect of Corticosteroids and Antibiotics (Table II)}

The number of patients involved is too small to give a statistically significant result. Of the fifteen patients whose cultures were initially negative, only three became positive after administration of the drops or ointment at least three times a day for not less than 2 weeks. The only comparable study is that of Mitsui and Hanabusa (1955). These authors selected eighteen patients in whom no fungi were demonstrable by smears or cultures, and then administered hydrocortisone ointment five or six times a day for 3 weeks. At the end of this time cultures were repeated; fungi were present in nine cases.

The present study does not demonstrate any such striking change in normal flora following the application of corticosteroids. But it must be pointed out that the Japanese workers used hydrocortisone ointment, whereas the patients in the present study were given betamethasone combined with neomycin (Betnesol-N, Glaxo). Little seems to be known about the effect of neomycin on fungi, and it cannot be assumed that the effect of the medication in either case would be identical.

As regards other antibacterial antibiotics, it is apparent that the effect of these on fungal growth and activity will vary with different antibiotics, different species of fungus, and different sites of infection. The view that wide-spectrum antibiotics should be withheld in all cases of ocular mycosis (e.g. Haggerty and Zimmerman, 1958) rests on rather slender evidence, much of which is conflicting. In the case of Candida albicans, Ley (1956), in experimental corneal infections in rabbits, claimed that 1 per cent. oxytetracycline strongly enhanced its virulence. And Seligmann $(1952,1953)$ showed that chlortetracycline and oxytetracycline enhanced the virulence of $C$. albicans in mice, though only when fungus and drug were administered intraperitoneally; in vitro no direct stimulation of growth of the fungus was evident (for criticisms of the work of Ley and of Seligmann, see Suie and Havener, 1963). Tanaka (1952) showed in vitro that chlortetracycline and oxytetracycline inhibited the growth of $C$. albicans at a concentration of 0.25 per cent., though they stimulated its growth at a concentration below 0.01 per cent. On the other hand, she found that the incidence of less pathogenic strains of Candida sp. isolated from cases of external eye infection undergoing treatment with antibiotics was not significantly different from that of control cases.

As regards other fungi, Ley (1956) found that chlortetracycline had no apparent effect on the virulence of Allescheria boydii or Aspergillus terreus in the rabbit cornea.

Thus, while administration of broad-spectrum antibiotics undoubtedly encourages fungal superinfection in certain sites such as the gut (Smith, 1952), there is little direct evidence that their topical application to the eye produces similar effects. By contrast, the effect of topical corticosteroids in this respect is well-documented (Hirose and others, 1957; Montana and Sery, 1958; Agarwal and others, 1963).

\section{Fungi isolated from Patients with Disease of the Outer Eye (Table III)}

Genera present in this group, which were not represented among the patients with healthy outer eyes, were Mucor, Alternaria, and Actinomyces. In nine of the 26 cases (34.6 per cent.) fungi were cultured, a proportion not significantly greater than that found among the patients in Group 1. For comparison, Azevedo (1962) described a series of 45 patients with disease of the outer eye of whom ten $(22 \cdot 2$ per 
cent.) had positive cultures, and Fazakas (1953) reported 823 positives from 2,214 diseased eyes ( 37 per cent.). In the present study no evidence was obtained which suggested a causal relationship between the presence of fungus and the disease in the eye from which it was isolated, except in Patient 8 (who had an actinomycotic infection of the lacrimal passages) and possibly Patient 2 (reported in more detail below). In none of the twenty patients (including the nine whose cultures were positive) from whom corneal smears were examined, was any growth of fungus seen microscopically.

\section{Case Report}

Patient 2, a 41-year-old lorry-driver, had good general health and no history of trauma to the eyes. On February 19, 1963, he presented with a history of discomfort affecting the right eye for 5 days.

Examination.-Visual acuity was 6/18 in the right eye and 6/5 in the left eye, which showed no abnormality. The right showed slight conjunctival injection, a central corneal nebula, and superficial punctate keratitis with diminished corneal sensation.

Treatment.-He was treated with neomycin ointment three times daily without improvement.

A virus keratitis was suspected and on March 8 corneal scrapings were taken for virus culture (which proved negative). The eye was then treated with neomycin ointment and a pad. A week later the visual acuity had improved to 6/12 and there was no conjunctival injection, though fine superficial erosions of the corneal epithelium persisted, and the nebula was unchanged. Since virus culture was negative, the treatment was changed to Betnesol-N drops (Glaxo) four times daily for $\mathbf{4}$ days, then neomycin drops three times daily.

Progress.-During the next 11 weeks the eye became more comfortable, and the visual acuity improved to 6/6, but the punctate corneal staining and the nebula persisted.

On May 7, during this period of improvement, a fungus culture was taken from the right eye, and two fungi were grown: P. chrysogenum and C. parapsilosis (=C. parakrusei; Fig. 1).

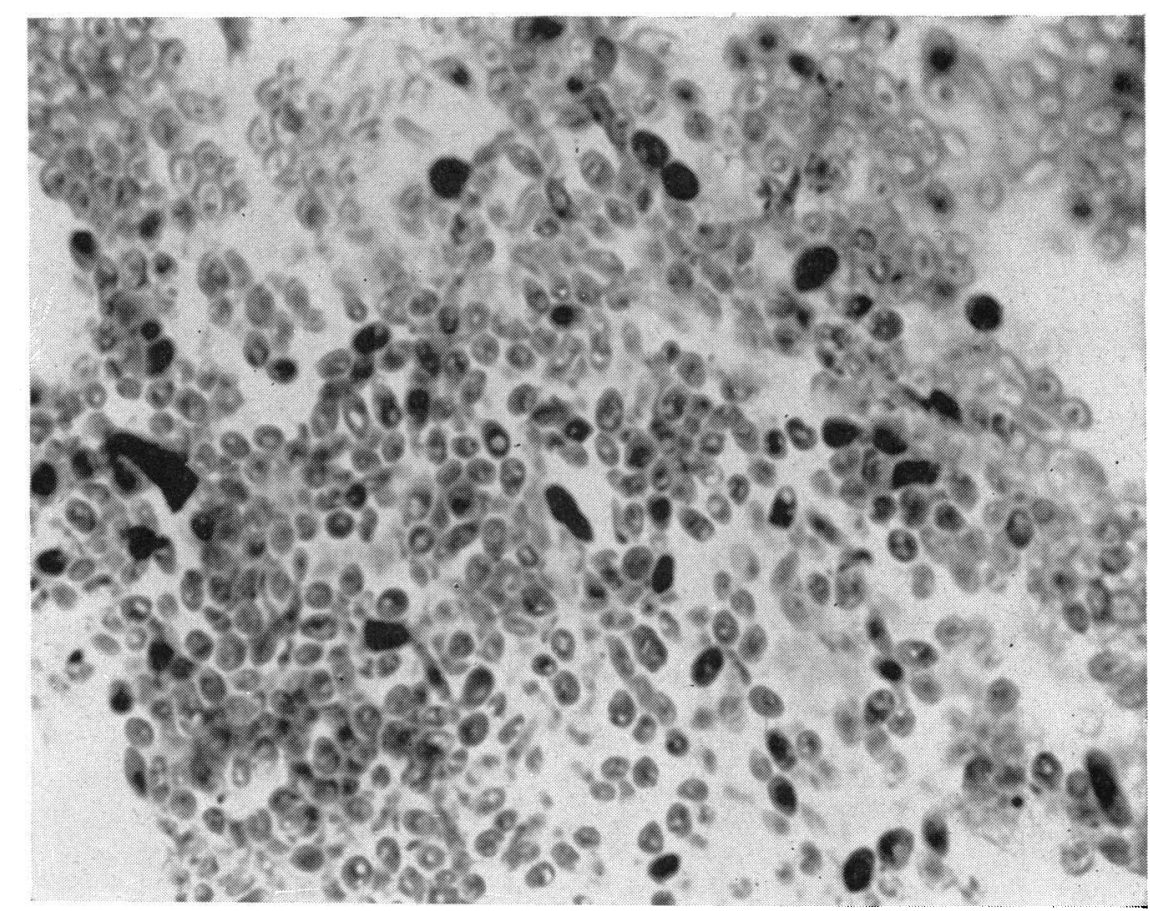

Fig. 1.-Candida parapsilosis. Smear of culture. Gridley's stain. $\times 850$ approx. 
On June 4 the eye had begun to show mild ciliary injection in addition to punctate staining. No flare or cells were present in the anterior chamber. Fungus cultures were taken from both eyes; that from the left was negative, but the culture from the right again produced a heavy growth of C. parapsilosis.

As a therapeutic trial (the identity of the fungus being as yet unknown) he was given a suspension of Nystatin (Squibb), 25,000 units/ml. to be used twice a day in the right eye; 4 days later he had no symptoms and the cornea had healed. Further fungus cultures were taken from each eye and both proved negative. The length of time for which the patient subsequently used Nystatin is not known, since he failed to keep the next appointment; 3 weeks later, however, he returned with a history of soreness affecting the right eye for 3 days, and was found to have a hypopyon ulcer from which Streptococcus pneumoniae (=Klebsiella) was isolated. The eye subsequently improved with subconjunctival penicillin and tarsorrhaphy.

\section{Laboratory Experiments}

In view of the repeated isolation of $C$. parapsilosis, a confluent culture of the fungus was tested for sensitivity to Nystatin suspension at dilutions of 500,5,000, and 50,000 units $/ \mathrm{ml}$. Inhibition of growth was observed at all dilutions (Fig. 2).

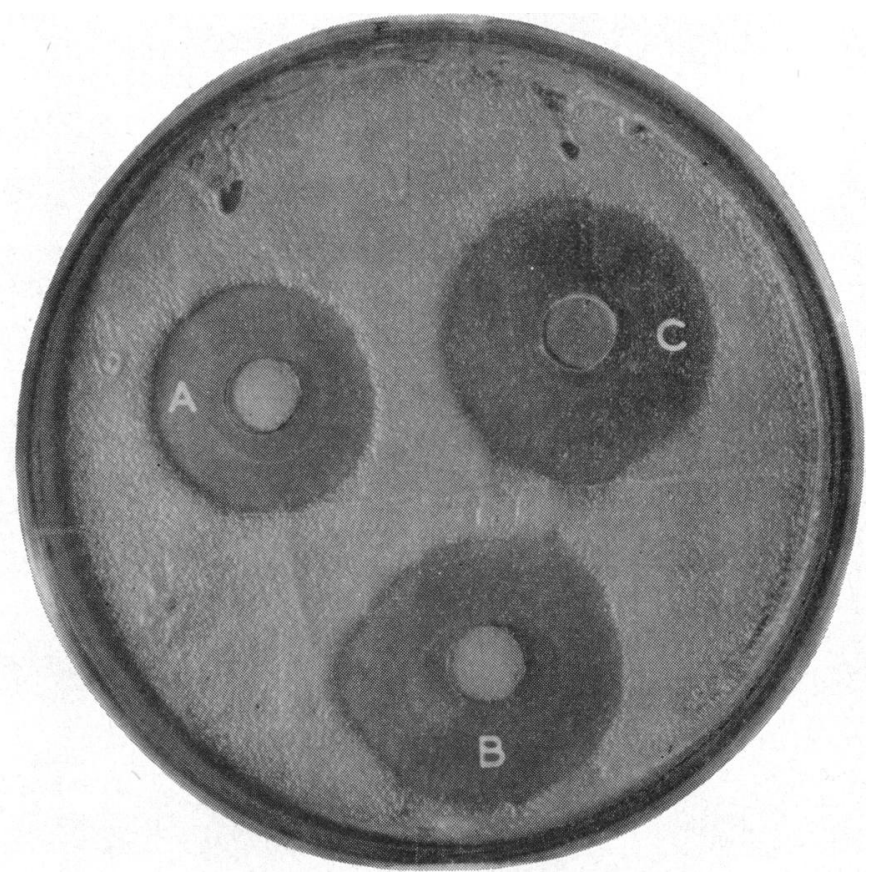

FIG. 2.-Assay plate, Nystatin suspension against confluent culture of Candida parapsilosis on Sabouraud agar. (A) 500 units $/ \mathrm{ml}$. (B) 5,000 units/ml. (C) 50,000 units/ml.

Methods.-Pathogenicity tests were performed on six guinea-pigs as follows. In every case the procedure described was performed on the right eye, the left serving as a control.

In four animals a linear corneal abrasion, confined to the epithelium, was inflicted by a sterile needle under local analgesia ( 2 per cent. cocaine drops), and the lesion verified by fluorescein staining and examination under a dissecting microscope.

In three of these animals, and two on which an abrasion had not been inflicted, a Sabouraud agar slope culture of the fungus was instilled into the conjunctival sac daily for 
TABLE VI

Pathogenicity Tests

\begin{tabular}{c|c|c|c}
\hline $\begin{array}{c}\text { Animal } \\
\text { No. }\end{array}$ & Day 1 & Days 2 and 3 & Days 4 to 8 \\
\hline 1 & Abrasion only & - & - \\
\hline 2 & Abrasion + fungus & Fungus & - \\
\hline 3 and 4 & $\begin{array}{c}\text { Abrasion + fungus } \\
+ \text { Betnesol-N t.i.d. }\end{array}$ & $\begin{array}{c}\text { Fungus } \\
+ \text { Betnesol-N t.i.d. }\end{array}$ & Betnesol-N t.i.d. \\
\hline 5 & Fungus only & Fungus only & - \\
\hline 6 & $\begin{array}{c}\text { Fungus } \\
+ \text { Betnesol-N t.i.d. }\end{array}$ & Betnesol-N t.i.d. & Betnesol-N t.i.d. \\
\hline
\end{tabular}

3 days. Betnesol-N (Glaxo) drops were given three times a day to two of the animals with abrasions and to one animal which had received fungus only (Table VI).

Administration of Betnesol- $\mathrm{N}$ was continued in the animals indicated for 8 days and the eyes were examined daily with a dissecting microscope after instilling fluorescein. The intention was to observe the effect of the fungus on the abraded cornea, and the influence of betamethasone/neomycin drops.

Results.-The corneal abrasions had been made from the centre of the cornea to the limbus at 12 o'clock. In animals 1 to 4 , hyperaemia of the bulbar conjunctiva appeared in the upper half on the day after the abrasion. By the fifth day the abrasions had healed completely. On the seventh day hyperaemia had disappeared and no signs of corneal pathology were detected.

When the experiments were repeated using fungus suspended in Sabouraud's broth diluted with phosphate buffer to $p \mathrm{H} 7.5$ and incubated at $37^{\circ} \mathrm{C}$. for 16 hours, the results did not differ significantly from those described above.

One week after final instillation of the fungus, cultures were taken from the right eye of each animal, and plated out on Sabouraud's agar. Positive cultures for C. parapsilosis were obtained from animals 3, 4, and 6 only.

\section{Discussion}

C. parapsilosis has been described as non-pathogenic for rabbits and guinea-pigs (Dodge, 1935). According to Conant, Smith, Baker, Callaway, and Martin (1954), C. albicans is the only member of the genus that is pathogenic for laboratory animals. Statements of this kind are of limited value unless the methods by which pathogenicity was assessed are taken into account. In the case of many fungus diseases, Koch's postulates have been notoriously difficult to fulfil, the present case being no exception. It is difficult to reproduce in animals the abnormal conditions under which mycotic superinfection occurs in man. That the fungus was playing a part either as a primary pathogen or, more probably, as a secondary invader in the case reported is suggested by the following considerations:

(a) A heavy growth of $C$. parapsilosis was obtained in two cultures taken at an interval of 28 days.

(b) It was obtained only from the affected eye.

(c) The patient became symptom-free after a short course of Nystatin drops, and it was shown in vitro that the fungus isolated was sensitive to Nystatin. 
No further attempt was made to produce keratomycosis in animals using the fungus isolated. The method using intracorneal injection of fungus along with subconjunctival corticosteroid was considered and rejected, as it was felt that the conditions of such an experiment would be too remote from those under which the patient's lesions developed to be meaningful.

It may be significant that in the pathogenicity tests $C$. parapsilosis could be recultured only from those guinea-pigs to which topical corticosteroid/neomycin drops had been administered. This might suggest that the drops interfere in some way with the normal defence mechanisms of the conjunctival sac, possibly by upsetting the ecological relationships between the fungus and the normal bacterial flora of the outer eye.

A previous case of ocular mycosis due to $C$. parapsilosis has been reported by Manchester and Georg (1959); these authors also refer to two cases reported in the Chinese Journal of Ophthalmology $(1957,7,101)$. Their patient was thought to have received corticosteroid and antibiotic drops for a long period before developing keratomycosis. As in the case reported above, the initial lesion was a superficial punctate keratitis, later cultures showed superinfection by a species of Klebsiella, and the keratomycosis improved with local Nystatin therapy. No attempt appears to have been made to reproduce the infection in animals, but fungus cells were present in a corneal smear, and C. parapsilosis was grown in culture on two occasions.

\section{Summary and Conclusions}

(1) A small survey of the fungal flora of the conjunctival sac was performed in healthy eyes before and after the administration of betamethasone-neomycin drops.

(2) The normal flora showed no striking differences from that found in surveys conducted in Central Europe, the United States, and Japan.

(3) The results do not confirm the findings of some previous workers that topical corticosteroids increase the incidence of fungi isolated. Possible reasons for this difference are discussed.

(4) Various fungi were isolated from a second series of patients with disease of the outer eye and adnexa. In two cases only was there any evidence that the fungus isolated was causally related to the disease, and one of these is reported as a possible case of secondary keratomycosis due to Candida parapsilosis (C. parakrusei).

(5) In pathogenicity tests of this fungus it was found that the organism could be recultured only from those animals to which betamethasone/neomycin drops had been administered.

(6) A greater awareness of the possibility of ocular mycosis might reveal that fungus infections are commoner in the United Kingdom than is suggested by the scarcity of reports in the literature.

The authors thank the surgeons of Oxford Eye Hospital for permission to investigate their patients, and especially Mr. J. P. F. Lloyd for encouragement and advice. It is a pleasure to thank Prof. G. A. G. Mitchell, of the Department of Anatomy, Manchester University, for facilities to perform the pathogenicity tests and for much helpful advice; Dr. R. W. Riddell, of the Department of Medical Mycology at the Institute of Dermatology, London, for identification of Candida parapsilosis; and Mr. F. L. R. Francis, of the School of Pathology, Oxford, for invaluable technical assistance. 


\section{REFERENCES}

Agarwal, L. P., Malik, S. R., Mohan, M., and Khosla, P. K. (1963). Brit. J. Ophthal., 47, 109.

Anderson, B., Roberts, S. S., Gonzalez, C., and Chick, E. W. (1959). A.M.A. Arch. Ophthal., $62,169$. AzEvedo, M. L. DE (1962). Arch. bras. Oftal., 25, 41.

BARSKY, D. (1959). A.M.A. Arch. Ophthal., 61, 547.

BIRGE, H. L. (1952). Ibid., 47, 354.

Chick, E. W., and ConANT, N. F. (1962). Invest. Ophthal., 1, 419.

Conant, N. F., Smith, D. T., Baker, R. D., Callaway, J. L., and Martin, D. S. (1954). "Manual of Clinical Mycology", 2nd ed. Saunders, Philadelphia.

Dodge, C. W. (1935). "Medical Mycology". Mosby, St Louis.

FAZAKas, A. (1935). Albrecht v. Graefes Arch. Ophthal., 133, 461. (1953). Ophthalmologica (Basel), 126, 91.

Fine, B. S., and Zimmerman, L. E. (1959). Amer. J. Ophthal., 48, 151.

Gordon, D. M. (1947). Arch. Ophthal. (Chicago), 37, 56.

HagGerty, T. E., and Zimmerman, L. E. (1958). Sth. med. J. (Bgham, Ala.), 51, 153.

HAMmeKe, J. C., and Ellis, P. P. (1960). Amer. J. Ophthal., 49, 1174.

Hirose, K., Yoshioka, H., Abe, S., Kanemitsu, J., and KiYA, K. (1957). $\quad$ Acta Soc. ophthal. jap., $61,1106$.

Hogan, M. J., Thygeson, P., and Kimura, S. (1954). Trans. Amer. ophthal. Soc., 52, 145.

LeY, A. P. (1956). Amer. J. Ophthal., 42, no. 4, pt 2, p. 59.

and SANDERS, T. E. (1956). A.M.A. Arch. Ophthal., 56, 257.

McGrath, H., and Singer, J. I. (1952). Amer. J. Ophthal., 35, 102.

McLean, J. M. (1963). Trans. Amer. Acad. Ophthal. Otolaryng., 67, 149.

Manchester, P. T. Jr., and Georg, L. K. (1959). J. Amer. med. Ass., 171, 1339.

Mankowski, Z. T., and Littleton, B. J. (1954). Antibiot. and Chemother., 4, 253.

Mikami, R., and Stemmermann, G. N. (1958). Amer. J. clin. Path., 29, 257.

Mitsui, Y., and Hanabusa, J. (1955). Brit. J. Ophthal., 39, 244.

Montana, J. A., and Sery, T. W. (1958). A.M.A. Arch. Ophthal., 60, 1.

Seligmann, E. (1952). Proc. Soc. exp. Biol. (N.Y.), 79, 481. (1953). Ibid., 83, 778.

Sigtenhorst, M. L., and Gingrich, W. D. (1957). Sth. med. J. (Bgham, Ala.), 50, 346.

SMITH, D. T. (1952). Ann. intern. Med., 37, 1135.

Suie, T., and HaVener, W. H. (1963). Amer. J. Ophthal., 56, 63.

TANAKA, C. (1952). Acta Soc. ophthal. jap., 56, 635.

Urrets-Zavalía, A., Remonda, C., and Ramacciotti, N. (1958). Amer. J. Ophthal., 46, 170.

VeIRS, E. R., and DAVIS, C. T. (1958). A.M.A. Arch. Ophthal., 59, 172.

WADSWORTH, J. A. C. (1951). Amer. J. Ophthal., 34, 405.

Weiss, C., Perry, I. H., and Shevky, M. C. (1948). Arch. Ophthal. (Chicago), 39, 739. 